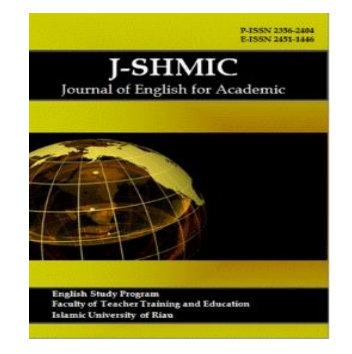

J-SHMIC : Journal of English for Academic

ISSN : 2641-1446 (Online) ISSN :2356-2404 (Print)

Homepage: https://journal.uir.ac.id/index.php/jshmic

Vol 8, No 2, August 2021

\title{
A Video-Mediated EFL Learning: Highlighting Indonesian Students' Voices
}

\author{
Sitti Hadijah ${ }^{1}$, Shalawati ${ }^{2}$ \\ Universitas Islam Riau ${ }^{1,2}$ \\ sittihadijah@edu.uir.ac.id ${ }^{1}$;shalawati@edu.uir.ac.id ${ }^{2}$
}

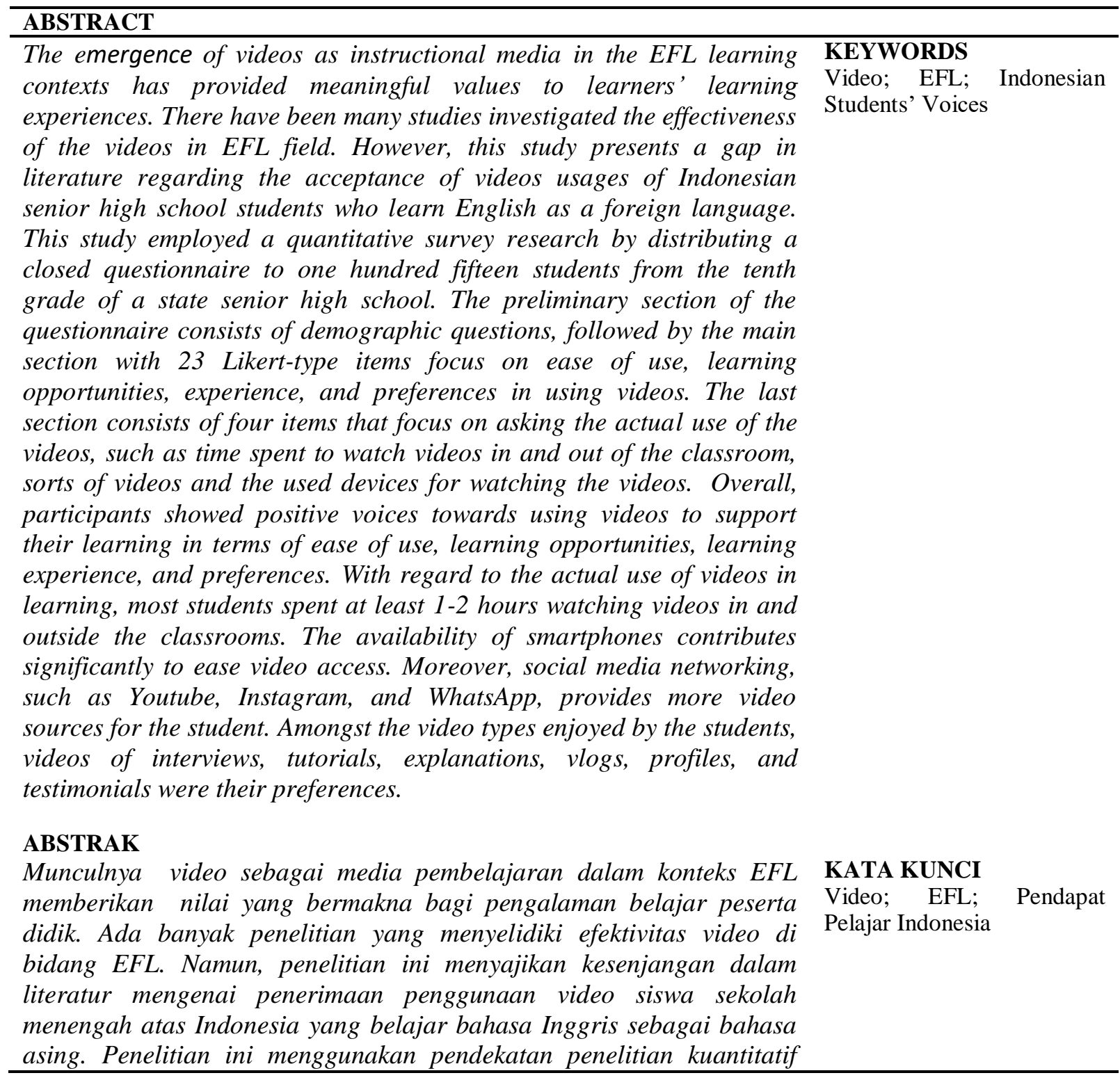


Sitti Hadijah ${ }^{1}$, Shalawati ${ }^{2}$

J-SHMIC : Journal of English for Academic

Vol 8, No 2, August 2021

dengan menyebarkan angket kepada seratus lima belas siswa kelas $X$ SMA Negeri. Bagian awal kuesioner terdiri dari pertanyaan demografis, diikuti oleh pertanyaan utama dengan 23 item tipe likert yang berfokus pada kemudahan penggunaan, peluang belajar, pengalaman, dan preferensi dalam menggunakan video. Bagian terakhir terdiri dari empat item yang berfokus pada menanyakan penggunaan dari video, seperti waktu yang dihabiskan siswa dalam belajar dengan menggunakan video di dalam dan di luar kelas, jenis video yang sering mereka tonton, dan perangkat yang digunakan untuk belajar. Penelitian ini menemukan penerimaan siswa pada penggunaan video dalam proses pembelajaran bahasa Inggris mereka. Secara keseluruhan, peserta menunjukkan respon yang positif terhadap penggunaan video untuk mendukung pembelajaran mereka dalam hal kemudahan penggunaan, kesempatan belajar, pengalaman belajar, dan preferensi. Terkait dengan penggunaan video dalam pembelajaran, sebagian besar siswa menghabiskan setidaknya 1-2 jam menonton video di dalam dan di luar kelas. Ketersediaan smartphone berkontribusi signifikan untuk memudahkan akses video. Selanjutnya, jejaring media sosial, seperti Youtube, Instagram, dan WhatsApp, menyediakan lebih banyak sumber video bagi siswa. Diantara berbagai jenis video yang dinikmati siswa, video wawancara, tutorial, penjelasan, vlog, profil, dan testimonial menjadi pilihan mereka.

\section{INTRODUCTION}

Technological advancement has shifted the educational field from traditional classroom settings that primarily work on printed learning resources into a technological-based learning system. This condition requires both teachers and students to use digital resources during the teaching and learning process. The use of videos as educational resources is one of the ways to run the teaching and learning process nowadays because videos have been widely available and accessible. The availability of camera-ready use, free streaming media hosting and sharing platforms, and recording studio on many campuses affect the widespread videos in educational contexts, (Ou et al., 2019). The rapid expansion of Youtube as the most wellknown videos sharing websites also influences the widespread of videos because it can facilitate the video creators to simply post their creations. Found on Youtube statistics, updated in 2020, the total number of monthly active Youtube users, videos watched per day, and hours of videos uploaded per minute are 2 billion, 1 billion, and 500, respectively.

Researchers have revealed the benefits of using videos in various educational contexts. For the development of of future teachers, using videos in the classroom can be a means to construct knowledge, develop skills, and create a critical video (Masats \& Dooly, 2011) in which it was effective in reflective practices functioning as a significant resources to remember lessons, observe learning performances, actively develop in critical reflection, and picture improvement (Kourieos, 2016; Serdar Tülüce \& Çeçen, 2018). In microteaching 
Sitti Hadijah ${ }^{1}$, Shalawati ${ }^{2}$

J-SHMIC : Journal of English for Academic

Vol 8, No 2, August 2021

subject for pre-service English teachers, videos were effective tools in reflective practices that function as a significant resource to remember lessons, observe learning performances, actively develop in critical reflection, and picture improvement (Kourieos, 2016; Serdar Tülüce \& Çeçen, 2018). Videos also develop critical thinking skills (Mete, 2020), facilitate different learning experiences, and better learning outcomes for higher education students in English language classes (Widodo \& Rozak, 2016).

Moreover, video is an effective tool to teach English because videos can present how the language is used naturally in various contexts of communication that can help the learners understand the language better (Harmer, 2007). Videos can also engage the students in the learning process because they contain audio visual information that can help teachers encourage them to participate in the lessons (Zıngır Gülten, 2017). Videos can also teach cultures and new ideas because they can introduce new cultures, places, and thoughts to the students (Farani \& Malang, 2019). In addition, video also provides more authentic materials that can facilitate EFL students to experience more realistic language learning environment, stimulate their interests, and enhance their communicative competence (Wang, 2014).

Although many videos for teaching and learning English are available on Youtube, English teachers still need to find appropriate videos to support their learning process. Abundances of videos can be onerous tasks for both teachers and students in selecting appropriate videos for the teaching and learning setting (McHugh \& McCauley, 2020). They usually have to invest their time searching for the best videos or spending their money to get relevant videos to their teaching and learning objectives.

To present appropriate instructional media in ELT context, particularly in Indonesia, the teachers should refer to the current syllabus that presents detailed description on what sort of content the teachers should deliver to enhance the students' English knowledge and skills. The current Indonesian curriculum, 2013 curriculum emphasizes building students' affective, cognitive, psychomotor competencies through scientific approaches; observing, questioning, associating, experimenting, and communicating. In this case, instructional media, such as video, becomes a cornerstone for the implementation of the 2013 curriculum in ELT context

Amidst the Covid-19 pandemic, many teachers have started to create their teaching videos and uploaded them on Youtube. Creating their videos is considered as one of the solutions to keep performing the teaching and learning process through an asynchronous or a synchronous learning system. This trend has significantly contributed to the availability of English video lessons on the internet. The potential implementation of videos in ELT context and a growing body of literature on the subject, the majority of research have mostly focused on the effectiveness of videos. In contrast, research on the acceptance and usage of videos from the perspective of Indonesian senior high school students in their English lessons is scarcely found. Therefore, this study aims to present this gap in the literature. 
Sitti Hadijah ${ }^{1}$, Shalawati ${ }^{2}$

J-SHMIC : Journal of English for Academic

Vol 8, No 2, August 2021

\section{METHOD}

This research worked on a quantitative survey research to explore EFL students' voices towards using video in English language learning. One hundred fifteen students from the tenth grade of a state senior high school in Pekanbaru, Riau province, Indonesia, participated in this study; they mostly have been learning English since elementary school. The age of individuals ranges from 14 to 17 years old, with the highest percentage of students were at 16 years old $(73.9 \%)$.

The students were voluntarily invited to fill out an online closed questionnaire through a Google Form. The questionnaire was adapted from an existing questionnaire from Bolliger et al., (2015). Regarding the objective of this study, some modifications were made to address the students' acceptances of using videos in EFL context.

The preliminary section of the questionnaire consists of demographic questions, followed by main section with twenty-three Likert-type items focus on ease of use, learning opportunities, experience, and preferences in using videos, ranging from 1-strongly disagree to 4-strongly agree. A neutral choice was not included to avoid central tendency bias. The last section of the questionnaire has four items, but they focus on asking the actual use of the videos, such as time spent by the students in learning by using videos in and out of the classroom, sorts of videos that they often watch, and also the devices used for watching the videos (See the appendix to find more detail information of the questionnaire's items).

Statistical data analyses were done to measure frequency, mean, and standard deviation (SD). Afterwards, the students' voices towards using video in their learning are presented based on four categories; ease of use, learning opportunities, experience, and preferences.

\section{FINDING AND DISCUSSION}

\section{Findings}

The findings of this study are discussed in accordance with the statements of problems formulated as follows: (1) what are students' perceptions of videos use pertaining to ease of use, learning opportunities, experiences, and preferences? (2) what is the actual use of videos in learning English? Each of the findings is described and provided with supporting data. The following section presents the detailed results of this research.

\section{Students' Perceptions of Videos Use in EFL Context}

\section{Ease of Use}

Table 1. Means and Standard Deviations for Ease of Use Items

\begin{tabular}{|c|l|c|c|c|}
\hline No. & \multicolumn{1}{|c|}{ Items } & F & Mean & SD \\
\hline 1. & Videos improve my learning performance. & 91 & 2.91 & 0.65 \\
\hline 2. & Videos increase my learning productivity & 94 & 2.91 & 0.53 \\
\hline 3. & Videos enhance my learning effectiveness. & 96 & 2.92 & 0.54 \\
\hline 4. & Videos help me to achieve better grades. & 93 & 2.92 & 0.59 \\
\hline 5. & $\begin{array}{l}\text { It would be easy for me to learn from video in the } \\
\text { classroom because of easy access of learning resources. }\end{array}$ & 91 & 2.98 & 0.67 \\
\end{tabular}


Sitti Hadijah ${ }^{1}$, Shalawati ${ }^{2}$

J-SHMIC : Journal of English for Academic

Vol 8, No 2, August 2021

Regarding videos' ease of use towards students' English learning, table 1 shows most of the students agreed or strongly agreed that videos could improve their learning performance, productivity, effectiveness, grades, and gott easy access to learning resources. Over $80 \%$ of students agreed or strongly agreed that using videos increased their learning productivity, effectiveness, and grades, and $79 \%$ of them also agreed or strongly agreed that videos improved their performance in English and got easy access to learning resources. The students' responses show that they have been using videos in their English learning process and using the videos easily in their learning.

\section{Learning Opportunities}

Table 2. Means and Standard Deviations for Opportunities

\begin{tabular}{|l|l|c|l|l|}
\hline No. & Items & F & Mean & SD \\
\hline 6. & Videos offer opportunities to have experiment with knowledge. & 104 & 3.08 & 0.50 \\
\hline 7. & Videos help me to take control of the learning process. & 88 & 2.86 & 0.55 \\
\hline 8. & Videos provide me to have experience of the things that I learn. & 109 & 3.09 & 0.45 \\
& & 111 & 3.2 & 0.46 \\
\hline 9. & Video facilitate transfer between various contents. & 82 & 2.79 & 0.65 \\
\hline 10. & Videos allow me to interact with other students. & 93 & 2.90 & 0.59 \\
\hline 11. & Videos offer me opportunities to think critically & 101 & 3.0 & 0.59 \\
\hline 12. & Videos motivate me in learning. & & \\
\hline
\end{tabular}

In terms of learning opportunities, table 2 depicts most of the students agreed or strongly agreed that videos offered opportunities for them to have experiment with knowledge, take control of the learning process, get experience in learning, accommodate transferring learning contents, interact with other students, think critically, and also motivate. $97 \%$ of the students agreed or strongly agreed that videos helped them to share various learning contents. Then $90 \%$ and $95 \%$ of the students also reported that videos allowed them to experiment with knowledge and experience their lessons. In addition, over $80 \%$ of students stated that learning by using videos helped them to think critically and got motivated in the learning process. Moreover, $71 \%$ and $77 \%$ of students claimed that videos were helpful as media for interacting with other students and controlling the learning process, respectively.

\section{Experience in Learning}

Table 3. Means and Standard Deviations for Experience in Learning

\begin{tabular}{|l|l|c|l|l|}
\hline No. & Items & F & Means & SD \\
\hline 13. & I like learning by using videos & 83 & 2.79 & 0.61 \\
\hline 14. & I often learn by using videos independently at home or out of school. & 70 & 2.68 & 0.66 \\
\hline 15. & I often learn by using videos in the classroom. & 66 & 2.59 & 0.59 \\
\hline 16. & Compared with people of my age, I watch a lot of videos. & 76 & 2.72 & 0.65 \\
\hline 17. & I would describe myself as video lover. & 56 & 2.51 & 0.64 \\
\hline 18. & I watch different types of videos. & 93 & 2.95 & 0.64 \\
\hline 19. & I often watch videos in Indonesian to learn English. & 101 & 2.95 & 0.51 \\
\hline 20. & I often watch videos in English to learn English. & 72 & 2.71 & 0.64 \\
\hline
\end{tabular}


As can be seen in table 3,72\% and $66 \%$ of students like learning English by using videos and watching many videos. $81 \%$ of the students watch different types of videos to support their English learning. They accounted for $88 \%$ of students who watch videos in Indonesian to learn English lessons. Meanwhile, the students who watch videos in English to learn English were less than $65 \%$. Interestingly, less than $50 \%$ of the students agreed or strongly agreed to describe themselves as video lovers, but $63 \%$ of students reported that they often learn by using videos autonomously out of the classroom. However, approximately half of the students disagreed or strongly disagreed with item no. 15, meaning that they were not quite often learning by using videos in the classroom.

\section{Preferences}

Table 4. Means and Standard Deviations for preferences

\begin{tabular}{|l|l|c|c|c|}
\hline No. & Items & F & Means & SD \\
\hline 21. & If I had a choice, I would take courses in which videos were used. & 75 & 2.68 & 0.60 \\
\hline 22. & I would be in favour of using videos in the classroom. & 76 & 2.72 & 0.68 \\
\hline 23. & I am enthusiastic about using videos in the classroom. & 82 & 2.76 & 0.59 \\
\hline
\end{tabular}

Table 4 presents over $60 \%$ of the students showed "strongly agree" and "agree" to all of the items addressed in the preference section. $71 \%$ of participants were enthusiastic about using videos in their English classrooms. However, the number of the students who were in favour of using videos in the classroom was a bit lower, accounted for only $67 \%$ of them who strongly agreed or agreed with the statement. Then, there were only $65 \%$ of the students who would take courses that used videos during the teaching and learning process.

Actual Use of Videos in EFL Context

1. Time spent for watching videos at school per week

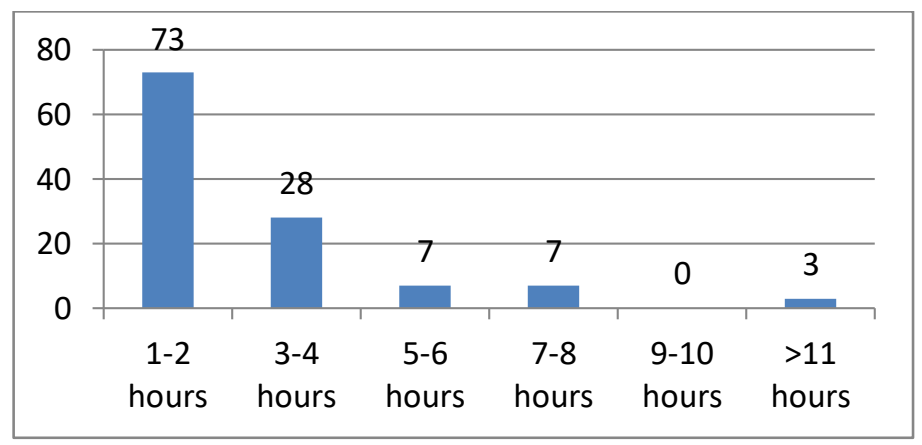

Figure 1: Time spent for watching videos at school per week

Figure 1 shows different hours spent by students watching videos at school per week. However, approximately $64 \%$ of the students spent 1-2 hours a week watching videos. Then, $24 \%$ of them allocated their time for 3-4 hours per week for watching videos. Meanwhile, $6 \%$ of the students watched videos or 5-8 hours per week; this number is two times higher than the number of students who spent over 11 hours per week watching videos at school. 


\section{Time spent watching videos at home per week}

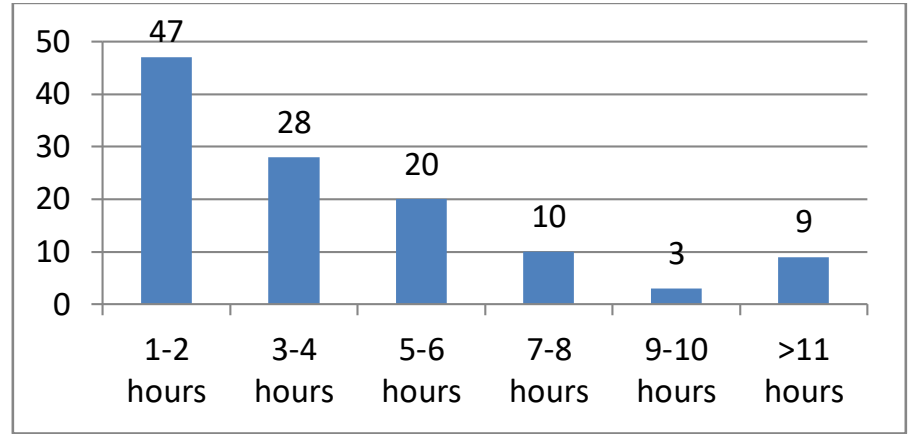

Figure 2: Time spent watching videos at school per week

Figure 2 depicts the time used by the students to watch videos out of their school hours per week. $41 \%$ of the students allocated their time for 1-2 hours a week to watch videos to learn English, while the rest watched videos in a range of 3-11 hours per week. Almost 50\% of the students watched videos at rang 3-8 hours per week. Meanwhile, only about $8 \%$ of the students spent over 11 hours watching videos after their school activities. Furthermore, only $2 \%$ of the students spent $9-10$ hours watching videos after school per week.

\section{Sources and Types of videos watched by the students}

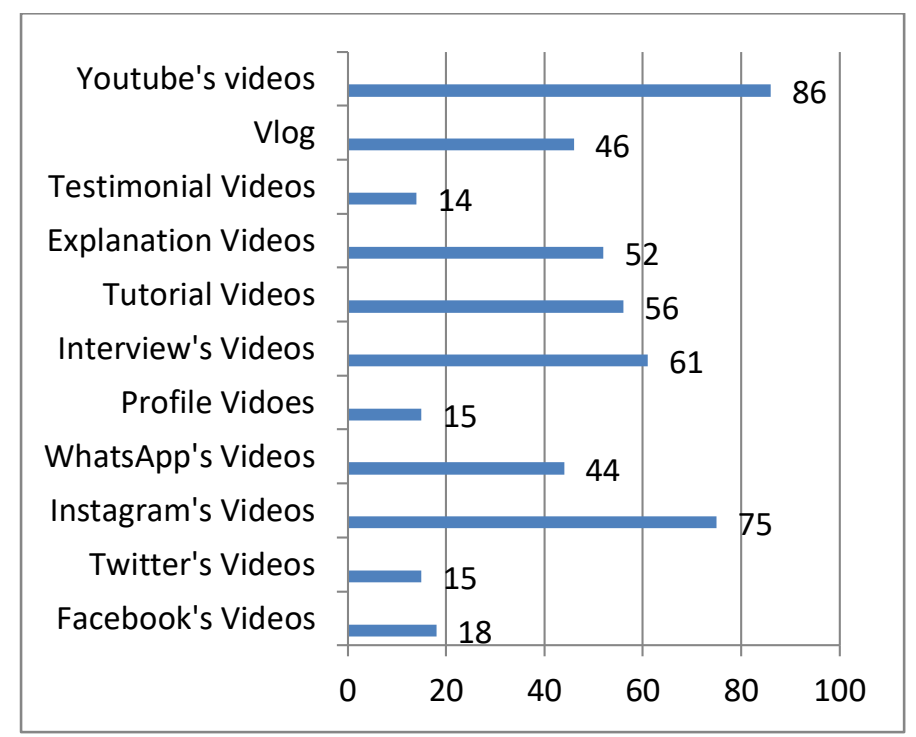

Figure 3: Types of videos watched by the students

Figure 3 represents the sources and sorts of videos that the students used to support their English language learning. Videos from Youtube placed the highest percentages with approximately $75 \%$ used by the students to watch videos. Then, the students also used 
Instagram (IG), with approximately $65 \%$ of them watch videos from this social media platform. Moreover, a number of students also used videos from WhatsApp (WA) to learn English, accounted for about 38\%, while videos from Twitter and Facebook were only watched by $16 \%$ and $13 \%$ of the students, respectively. However, in terms of the kinds of videos watched by the students to learn English, they chose to watch videos of interviews $(53 \%)$, tutorials (49\%), explanations (45\%), vlogs (40\%), profiles (13\%), and testimonials $(12 \%)$.

\section{Tools for watching videos}

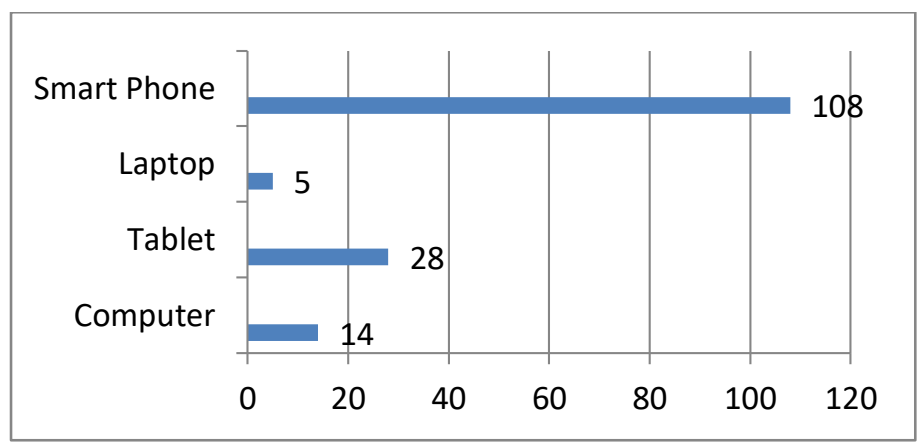

Figure 4: Tools for watching videos

Figure 4 reported that the students have primarily used a smartphone to learn English with videos, 93\%. Tablet placed the second category after smartphone, with the number of users being $24 \%$, while the computer users were only half of the tablet users. Surprisingly, only a few students who used laptops to watch videos in learning English accounted for about $4 \%$.

\section{Discussion}

\section{Students' Perceptions of Videos Use in EFL Context}

In terms of Indonesian senior high school students' voices in using videos in EFL context, this research found the students' acceptance on video uses in their language learning. Based on the focus of this study, the students' voices on videos were categorized into ease of use, learning opportunities, experience in learning, preferences, and actual use. The data found in this research picture detail the significance of videos use in learning English as a foreign language.

Regarding the ease of using videos based on the students' voices, videos could improve their learning performances. In English language learning context, Cowie \& Sakui (2021) identified some easiness of using videos for students; help them to practice the language, for example in speaking skill in which they can practice speaking to their classmates or teachers at different level of formality from casual information sharing to a more formal presentation; facilitate the students to report on what they have learnt or summarized reflect on other skills that they have practiced; provide authenticity and increase motivation in the language learning process because the students can create and share their 
Sitti Hadijah ${ }^{1}$, Shalawati ${ }^{2}$

J-SHMIC : Journal of English for Academic

Vol 8, No 2, August 2021

videos, so it can encourage them to frequently practice the language. In other words, the students do not only watch or learn something from videos, but they can also create and share their videos to show their mastery in learning English. Besides, the video tasks made by the students can be an instrument to measure the students' performance through selfassessment video (Hidalgo Rojas, 2021). Finally, the students can also get easy access to learning resources to improve their English, such as watching their friends' videos or browsing or downloading related videos contents to their lesson. In this case, a teacher in the classroom has to know well how to work on videos as an instructional tool to facilitate better achievement in English learning context (Hadijah, 2016).

Another significant of videos in English language teaching context related to learning opportunities for the students. Cowie \& Sakui (2021) stated that learning through videos can facilitate the language learners to practice the language in a more authentic situation. By watching videos of English native speakers, the students can learn how the language is used naturally by the speakers. The learning opportunities that the students could access through videos are precious because they could easily find out the native speakers to practice the language. In addition, the students could enhance their multicultural competence through videos; they could have better awareness, knowledge, and skills that relate to cultural diversity in the language learning process (Lin \& Wang, 2018). The availability of Youtube as a video sharing platform can enrich the students' knowledge and develop their skills (Saud Albahlal, 2019). Learning through videos can also help the students interact with the other students in the classroom or out of the classroom and talk about the video contents or give feedback or suggestions. The teachers should be able to use this opportunity to present more innovative learning activities for the students. Eventually, the communication activities that could happen through videos can also be used to train the students to think critically (Mete, 2020).

Furthermore, students' experiences in learning English through videos also showed positive vibes in this study. Previous studies have revealed that the benefits of videos towards the students' learning experiences are various; improve language skill (Hidalgo Rojas, 2021); (Saud Albahlal, 2019), enhance students' multicultural competence (Lin \& Wang, 2018), provide more learning resources (Anugerah et al., 2019; S, 2021). However, this study found that most of the students watch videos in their native language (Indonesian), instead of using English in their learning process. The students in this research might assume themselves as beginner learners who still need comprehensive explanations in Indonesian while watching a video to learn English. This finding is inverse the previous research of Mahmoud Al-Zoubi (2018) that found a strong effect of exposing English towards 42 English foreign language learners' acquisition of English. Furthermore, half the students in this study did not want to describe themselves as videos lovers. This finding reveals that videos are not the only digital learning resources used by the students to expand and develop their English knowledge and skills.

Although a cohort of the students did not claim themselves as video lovers, most of them also showed their preferences in using videos during their learning activities; they feel excited when learning by using videos. This finding supports some previous studies that using videos in the classroom could engage students in their learning process (Pirhonen \& Rasi, 2017; Long et al., 2016). In addition, this study also recommends English language 
Sitti Hadijah ${ }^{1}$, Shalawati ${ }^{2}$

J-SHMIC : Journal of English for Academic

Vol 8, No 2, August 2021

teachers more often using videos in their teaching and learning activities because the students in this study are eager to follow their courses when videos are used.

\section{The Actual Use of Videos in EFL Context}

For the actual use of videos in learning English, the students showed that videos were used quite intense. Most of them spent at least 1-2 hours a week watching videos to learn English in and outside of the classrooms. This finding proved that the learners have been closely connected with videos to support their English learning process. It is in line with Brame (2016), stating that videos become a cornerstone to help students learn both in blended learning and online learning systems. However, teachers have to guide the students to find effective educational videos to help them in their learning process. To optimize the use of videos, when a teacher designs or implements videos in teaching, the videos should contain three aspects; cognitive load, students engagement, and active learning (Brame, 2016). In other words, the videos for the students should function to expand the students' understanding, encourage them to be involved in their learning process, and make them active and innovative.

In terms of sources and sorts of videos used by the students in their English learning process, YouTube is the most accessed platform by the students. Many studies have found the effectiveness of using YouTube videos for educational purposes (Anugerah et al,. 2019; Saud Albahlal, 2019) However, YouTube is not the only platform used by the students; social media such as Instagram also facilitated the students to access videos to learn English since many videos can be found on Instagram. Sagadavan \& John ( 2019) identified YouTube, Instagram, and Facebook as three preferred social media sites among Malaysian tertiary students to receive their instructors' guidance. Even though some scholars have investigated the use of social media as learning platforms (Martin et al., 2020), this study reveals an alternative way for teachers in teaching English by using Instagram and videos. Using Instagram as a means for creating and sharing English videos contents can be more engaging for the students at senior high school levels since many young people have Instagram as their social media platform, so it can bring innovation in teaching and learning context and provide a joyful learning atmosphere which is one of core needs for the students. As stated by Hidayati et al., (2021), positive feeling, such as joyful bring significant role in English language teaching, especially in online setting. Then, the use of WhatsApp (WA) also facilitated the students to get videos to learn (Martin et al., 2020). Sagadavan \& John (2019); Arifani et al., (2020) found the effectiveness of WA to teach vocabulary to the students. In this case, using WA as a social media platform for sharing learning resources and performing learning activities bring positive values for the students. However, a few students only used social media Twitter and Facebook to get their learning videos.

In relation to the sorts of videos watched by the students in their English learning process, teachers should provide relevant videos for the students by considering some factors, not only about what have been spelt out in the syllabus, but the videos should relate to the students' interest that will bring positive emotions in their learning. This study also found six types of videos that the students enjoyed watching to support their English learning; interview, tutorial, explanation, profile, and testimonial videos. 
Sitti Hadijah ${ }^{1}$, Shalawati ${ }^{2}$

J-SHMIC : Journal of English for Academic

Vol 8, No 2, August 2021

\section{CONCLUSION}

The present study reveals the Indonesian EFL students' acceptance of using videos in their English language learning process. Overall, participants accentuated positive voices towards the use of videos to support their learning in terms of the ease of use, learning opportunities, learning experiences, and preferences. It is undeniable that nowadays, videos could be easily accessed by the students to improve their knowledge and skills in English. The advancement of technology does not only facilitate learning opportunities for the students to get access to their English video lessons quickly, but also create their English video content to practice the language and expand their language learning experiences. However, the teachers need to be creative and innovative when working with videos in their English classrooms to get meaningful learning experiences and get interested in their learning activities.

Regarding the actual use of videos to support learning, most students spent at least 1-2 hours watching videos in and outside the classrooms. The availability of smartphones contributes significantly to the ease of video access. Moreover, social media networking, such as YouTube, Instagram, and WhatsApp, provides more videos sources for the students. In this case, the teachers should optimize the use of social media as a means of engaging the students in learning English, especially to share video contents or make their own English video contents. In terms of video types, the videos enjoyed by the students were classified into videos of tutorials, explanations, vlogs, profiles, and testimonials. It is necessary for the teachers to know sorts of videos that the students prefer to watch because it can bring positive emotions in their learning process.

This research project has investigated EFL students' voices in using videos in their learning process. Although this study has found the students' acceptance in learning English through videos, this study cannot draw general conclusions in other contexts because there were only 115 participants from a state senior high school in Pekanbaru involved. In addition, the researcher believes that there is a gap in undertaking a structured interview with educational leaders, such as headmaster, teachers, and parents, to raise other concerns. Indeed, the acceptance of videos might also be different.

This study has reiterated that using videos in EFL context bring benefits for students. The findings of this study should be investigated further through interviews to further research the students' reasons for their acceptance of the use of videos in their language learning process. More specifically, further research might also investigate the students' acceptance of using videos utilizing the qualitative scrutiny or mixed approach and explore the motivational appeal of learning English through videos. Furthermore, there is a scope in analyzing teachers and students' made videos towards their contributions in students' behaviours and skills in learning English.

\section{REFERENCES}

Anugerah, R., Gatot, Y., Yuliana, S., \& Riyanti, D. (2019). the Potential of English Learning Videos in Form of Vlog on Youtube for Elt Material Writers. FKIP Universitas Tanjungpura, 2(2), 2685-1407. http://jurnal.untan.ac.id/index.php/icote/article/view/38232 
Sitti Hadijah ${ }^{1}$, Shalawati ${ }^{2}$

J-SHMIC : Journal of English for Academic

Vol 8, No 2, August 2021

Arifani, Y., Asari, S., Anwar, K., \& Budianto, L. (2020). Individual or collaborative whatsapp learning? A flipped classroom model of efl writing instruction. Teaching English with Technology, 20(1), 122-139.

Bolliger, D. U., Mills, D., White, J., \& Kohyama, M. (2015). Japanese students' perceptions of digital game use for English-language learning in higher education. Journal of Educational Computing Research, 53(3), 384-408.

Brame, C. J. (2016). Effective educational videos: Principles and guidelines for maximizing student learning from video content. CBE Life Sciences Education, 15(4), es6.1-es6.6. https://doi.org/10.1187/cbe.16-03-0125

Farani, Y., \& Yustisia, Karlina Karadila. (2019). Using Texts and Videos to Integratedly Teach Culture through Business English Of ESP 1 Subject. ISoLEC (International Seminar on Language Education and Culture, October.

Hadijah, S. (2016). Teaching by Using Video: Ways to Make it More Meaningful in EFL Classrooms. Proceedings of the Fourth International Seminar on English Language and Teaching ISELT-4, October, 307-315.

Harmer, J. (2007). The practice of English language teaching. Harlow. England: Pearson Education.

Hidalgo Rojas, M. E. (2021). Self-Assessing Students'Videos to Improve Speaking Skills [Universidad Casa Grande. Departamento de Posgrado]. http://dspace.casagrande.edu.ec:8080/handle/ucasagrande/2672

Hidayati, A. N., Ramalia, T., \& Abdullah, F. (2021). Leveraging Skype-based webinars as an English language learning platform. AL-ISHLAH: Jurnal Pendidikan, 13(1), 10-20. https://doi.org/10.35445/alishlah.v13i1.420

Kourieos, S. (2016). Video-mediated microteaching-A stimulus for reflection and teacher growth. Australian Journal of Teacher Education, 41(1), 65-80. https://doi.org/10.14221/ajte.2016v41n1.4

Lin, Y. J., \& Wang, H. C. (2018). Using enhanced OER videos to facilitate English L2 learners' multicultural competence. Computers and Education, 125(October 2017), 7485. https://doi.org/10.1016/j.compedu.2018.06.005

Long, T., Logan, J., \& Waugh, M. (2016). Students' perceptions of the value of using videos as a pre-class learning experience in the flipped classroom. TechTrends, 60(3), 245252.

Mahmoud Al-Zoubi, S. (2018). The Impact of Exposure to English Language on Language Acquisition. Journal of Applied Linguistics and Language Research, 5(4), 151-162. www.jallr.com

Martin, F., Dennen, V. P., \& Bonk, C. J. (2020). A synthesis of systematic review research on emerging learning environments and technologies. Educational Technology Research and Development, 68(4), 1613-1633. https://doi.org/10.1007/s11423-02009812-2

Masats, D., \& Dooly, M. (2011). Rethinking the use of video in teacher education: A holistic approach. Teaching and Teacher Education, 27(7), 1151-1162. https://doi.org/10.1016/j.tate.2011.04.004

McHugh, M., \& McCauley, V. (2020). By Hook or by Crook: Designing Physics Video Hooks with a Modified ADDIE Framework. Journal of Applied Instructional Design, 
9(3), 1-13. https://doi.org/10.51869/93mmhvmc

Mete, D. E. (2020). Fostering critical thinking skills in ELT through video-based reflection. Journal of Language and Linguistic Studies, 16(1), 104-125. https://doi.org/10.17263/JLLS.712662

Ou, C., Joyner, D. A., \& Goel, A. K. (2019). Designing and developing video lessons for online learning: A seven-principle model. Online Learning Journal, 23(2), 82-104. https://doi.org/10.24059/olj.v23i2.1449

Pirhonen, J., \& Rasi, P. (2017). Student-generated instructional videos facilitate learning through positive emotions. Journal of Biological Education, 51(3), 215-227.

S, J. P. (2021). Video Based Learning as a Media for Teaching English during Pandemic Covid-19. Journal of Language Intelligence and Culture, 2(1), 1-11. https://doi.org/10.35719/jlic.v2i1.53

Sagadavan, R., \& John, S. (2019). Learning preferences transformation in tertiary education. International Journal of Recent Technology and Engineering, 8(2 Special Issue), 215220.

Saud Albahlal, F. (2019). The Impact of YouTube on Improving Secondary School Students' Speaking Skills: English Language Teachers' Perspectives. Journal of Applied Linguistics and Language Research, 6(2), 1-17. www.jallr.com

Serdar Tülüce, H., \& Çeçen, S. (2018). The use of video in microteaching: affordances and constraints. ELT Journal, 72(1), 73-82. https://doi.org/10.1093/elt/ccx028

Wang, Z. (2014). An Analysis on the Use of Video Materials in College English Teaching in China. International Journal of English Language Teaching, 2(1), 23-28. https://doi.org/10.5430/ijelt.v2n1p23

Widodo, H. P., \& Rozak, R. R. (2016). Engaging Student Teachers in Collaborative and Reflective Online Video-Assisted Extensive Listening in an Indonesian Initial Teacher Education (ITE) Context. Electronic Journal of Foreign Language Teaching, 13(2), 229-244.

Zingır Gülten, A. (2017). Trainees' perceptions of video use in English language teaching: Digital natives' turn. International Journal of Social Sciences and Education Research, 3(1), 250-250. https://doi.org/10.24289/ijsser.271023 


\section{APPENDIX}

Blue print of a closed questionnaire that focuses on Indonesian students' voices towards the use of Videos in EFL context.

\begin{tabular}{|c|c|c|c|}
\hline No. & Components & Items & Scale Ranging \\
\hline 1. & Ease of Use & $\begin{array}{l}\text { a. Videos improve my learning } \\
\text { performance. } \\
\text { b. Videos increase my learning } \\
\text { productivity } \\
\text { c. Video enhance my learning } \\
\text { effectiveness. } \\
\text { d. Video help me to achieve } \\
\text { better grades. } \\
\text { e. It would be easy for me to } \\
\text { learn from video in the } \\
\text { classroom. }\end{array}$ & $\begin{array}{l}1 \text { (strongly } \\
\text { disagree) to } 4 \\
\text { (strongly agree). }\end{array}$ \\
\hline 2. & $\begin{array}{l}\text { Learning } \\
\text { Opportunities }\end{array}$ & $\begin{array}{l}\text { a. Videos offer opportunities to } \\
\text { experiment with knowledge. } \\
\text { b. Videos help me to take } \\
\text { control the learning process. } \\
\text { c. Videos provide me to } \\
\text { experience the things that I } \\
\text { learn. } \\
\text { d. Video facilitate transfer } \\
\text { between various contents. } \\
\text { e. Videos give opportunity for } \\
\text { me to interact with other } \\
\text { students. } \\
\text { f. Videos offer the } \\
\text { opportunities to think } \\
\text { critically } \\
\text { g. Videos motivate me in } \\
\text { learning. }\end{array}$ & $\begin{array}{l}1 \text { (strongly } \\
\text { disagree) to } 4 \\
\text { (strongly agree). }\end{array}$ \\
\hline 3. & Experiences & $\begin{array}{l}\text { a. I like learning by using } \\
\text { videos } \\
\text { b. I often learn by using videos } \\
\text { independently at home or out } \\
\text { of school. } \\
\text { c. I often learn by using videos } \\
\text { in the classroom. }\end{array}$ & $\begin{array}{l}1 \text { (strongly } \\
\text { disagree) to } 4 \\
\text { (strongly agree). }\end{array}$ \\
\hline
\end{tabular}




\begin{tabular}{|c|c|c|c|}
\hline & & $\begin{array}{l}\text { d. Compared with people of my } \\
\text { age, I watch a lot of videos. } \\
\text { e. I would describe myself as } \\
\text { video lovers. } \\
\text { f. I watch different types of } \\
\text { videos. } \\
\text { g. I often watch video in } \\
\text { Indonesian to learn English. } \\
\text { h. I often watch video in } \\
\text { English to learn English. }\end{array}$ & \\
\hline 4. & Preferences & $\begin{array}{l}\text { a. If I had a choice, I would } \\
\text { take courses in which videos } \\
\text { were used. } \\
\text { b. I would be in favor of using } \\
\text { videos in the classroom. } \\
\text { c. I am enthusiastic about using } \\
\text { videos in the classroom. }\end{array}$ & $\begin{array}{l}1 \text { (strongly } \\
\text { disagree) to } 4 \\
\text { (strongly agree). }\end{array}$ \\
\hline 5. & Actual Use & $\begin{array}{l}\text { a. Average hours per week to } \\
\text { watch videos at school. } \\
\text { b. Average hours per week to } \\
\text { watch videos out of school. } \\
\text { c. Types of videos watched. } \\
\text { d. Items used to watch videos }\end{array}$ & $\begin{array}{l}\text { For items a and } \\
\text { b: } \\
\text { Multiple Choices. } \\
\text { Fort items c and } \\
\text { d: } \\
1 \quad \text { (never) to } \\
5 \text { (very } \\
\text { frequently) } \\
\text { Never } \\
\text { rarely(2), (1), } \\
\text { occasionally (3), } \\
\text { frequently (4), } \\
\text { very frequently } \\
\text { (5). }\end{array}$ \\
\hline
\end{tabular}

